TITLE: REVIEN OF LIQUID METAL HEAT PIPE WORK AT LOS ALAMOS

AUTHOR(S): Robert S. Reid, MEE-13

Michael A. Merrigan, MEE-13

J. Tom Sena, MEE-13

SUBMITTED TO:

The 8th Symposium on Space Nuclear Power Systems

Institute for Space Nuclear Power Studies

Chemical \& Nuclear Engineering Department

The University of New Mexico

Albuquerque, New Mexico 87131

To be held January $6-10,1991$ 
$\log$ Nr. 200

\title{
Review of Liquid Metal Heat Pipe Work at Los Alamos
}

\author{
Robert S. Reid \\ Michael A. Merrigan \\ J. Tom Sena \\ Los Alamos National Laboratory \\ P.O. Box 1663 \\ Los Alamos, New Mexico 87545 \\ (505) 667-2626 \\ FTS $843-2626$
}

CAMERA READY MANUSCRIPT prepared for:

Eighth Symposium

on Space Nuclear Power Systems

Albuquerque, New Mexico

6-10 January 1991

initial submission: 1 November 1990

Author to whom correspondence should be sent:

Robert S. Reid (for all questions)

\section{DISCLAIMER}

\begin{abstract}
This report was prepared as an account of work sponsored by an agency of the United States Government. Neither the United States Government nor any agency thereof, nor any of their employees, makes any warranty, express or implied, or assumes any lega! liability or responsibility for the accuracy, completeness, or usefulness of any information, apparatus, product, or process disclosed, or represents that its use would nut infringe privately owned rights. Reference herein to any specific commercial product, process, or service by trade name, trademark, manufacturer, or otherwise does not necessarily constitute or imply its endorsement, recommendation, or favoring by the United States Government or any agency thereor. The views and opinions of authors expressed herein do not necessarily state or reflect those of the United Sitates Government or any agency thereor.
\end{abstract}




\title{
Review of Liquid Metal Heat Pipe Work at Los Alamos
}

\author{
Robert S. Reid \\ Michael A. Merrigan \\ J. Tom Sena \\ Los Alamos National Laboratory \\ P.O. Box 1663 \\ Los Alamos, New Mexico 87545 \\ (505) $667-2626$ \\ FTS 843-2626
}

\begin{abstract}
A survey of space-power related liquid metal heat pipe work at Los Alamos National Laboratory is presented. Heat pipe development at Los Alamos has been on-going since 1963. Heat pipes were initially developed for thermionic nuclear-electrical power production in space. Since then Los Alamos has developed liquid metal heat pipes for numerous applications related to high temperature systems in both the space and terrestrial environments. Some of these applications include thermionic electrical generators, thermoelectric energy conversion (both in-core and direct radiation), thermal energy storage, hypersonic vehicle leading edge cooling, and heat pipe vapor laser cells. Some of the work performed at Los Alamos has been documented in internal reports that are often little-known. A representative description and summary of progress in space-related liquid metal heat pipe technology is provided followed by a reference section citing sources where these works may be found.
\end{abstract}

\section{INTRODUCTION}

On July 24, 1963, George Grover made the following entry into his laboratory notebook: "Heat transfer via capillary movement of fluids. The "pumping" action of surface tension forces may be sufficient to move liquids from a cold temperature zone to a high temperature zone (with subsequent return in vapor form using as the driving force, the difference in vapor pressure at the two temperatures) to be of interest in transferring heat from the hot to the cold zone. Such a closed system, requiring no external pumps, may be of particular interest in space reactors in moving heat from the reactor core to a radiating system. In the absence of gravity, the forces must only be such as to overcome the capillary and the drag of the returning vapor through its channels."

Thus began heat pipe research at Los Alamos. Later that year Grover submitted the results of "heat pipe" experiments with water and sodium as vorking fluids to the Journal of Applied Physics (Grover et al., 1964). The sodium heat pipe, $90 \mathrm{~cm}$ long with a 1.9 $\mathrm{cm}$ O.D., operated at $1100 \mathrm{~K}$ with $1-\mathrm{kW}$ heat input. This paper reviews the 28 years of space power-related liquid metal heat pipe research that has been conducted at Los Alamos since the invention of the heat pipe. 


\section{THERMIONIC REACTOR PROGRAM APPLICATIONS}

Early research in heat pipes conducted at Los Alamos was directed to applications in space-based thermionic energy conversion systems operating in excess of $1500 \mathrm{~K}$. Heat pipes were considered for heating thermionic emitters, for cooling thermionic collectors, and for the ultimate radiation of heat to space. Fluids and materials were tailored to this temperature regime. Experiments with a $\mathrm{Nb}-1 \% \mathrm{Zr}$ heat pipe, with lithium operating at $1573 \mathrm{~K}, 207 \mathrm{~W} / \mathrm{cm}^{2}$ evaporator radial heat flux; a $1.95 \mathrm{~kW} / \mathrm{cm}^{2}$ axial heat flux, and an $\mathrm{Ag}$ Ta operating at $2273 \mathrm{~K}, 410 \mathrm{~W} / \mathrm{cm}^{2}$ evaporator radial heat flux; and a $4 \mathrm{~kW} / \mathrm{cm}^{2}$ axial heat flux are reported in Deverall and Kemme (1964). The results of early thermionic-related heat pipe fluid-wall compatibility and life test studies with systems of In-W at $2173 \mathrm{~K}$ for 75 hours, Ag-Ta at $2173 \mathrm{~K}$ for 100 hours, Cs-Ti at $673 \mathrm{~K}$ in excess of 2000 hours, Nastainless steel at $1073 \mathrm{~K}$ for 500 hours, and Li-Nb-1\% Zr at $1373 \mathrm{~K}$ for 4300 hours are summarized in Grover et al. (1964), Deverall and Kemme (1964), Grover et al. (1965), Cotter et al. (1965), and Ranken and Kemme (1965). A study characterizing both potassium and sodium heat pipes with various wick structures and a treatment of the limitations to heat pipe start-up and operation is contained in Kemme (1966).

\section{Development of Heat Pine Theory}

A number of early Los Alamos pape:- have presented general quantitative principles of heat pipe operation. Cotter (1965) presented an overview of heat pipe start-up and steadystate heat pipe operation. He discussed the capillary and the boiling limits to heat pipe operation and considered the operating characteristics of heat pipes with multicomponent fluid. A set of analytical steady-state equations describing the flow of vapor in the vapor space was also included. Transient modes of heat pipe start-up and failure are described in Cotter (1967). A general treatment of the sonic, entrainment, capillary, and boiling limits in liquid metal heat pipes are given in Kemme (1968), Kemme (1969), and Deverall et al. (1970). These papers consider various wick structures including arteries, open channels, screens, concentric and crescent annuli. Deverall et al. (1970) also gives a characterization of start-up failure modes due to externally imposed boundary conditions and the presence of noncondensable gas in liquid metal pipes. They provided experimental and quantitative results of sonic limitation to the start-up of mercury heat pipes and experimental and qualitative descriptions of evaporator entrainment, condenser freeze-out, and capillary failure. Several computer codes have been developed to quantitatively model various aspects of both steady-state (analytically based) Woloshun et al. (1988), and transient (numerically based) Costello et al. (1987) heat pipe operation. HTPIPE, the current Los Alamos steady state heat pipe performance analysis program, has been verified extensively with experiment. Some recent efforis have attempted to correlate entrainment in gravity-assist potassium heat pipes Merrigan et al. (1987) and predict boiling limits in potas sium heat pipes with annular gap wicks Woloshun et al. (1990b). A thermochemical corrosion model using a free energy minimization routine coupled to a hydrodynamic model of liquid metal heat pipe system is described in Merrigan and Feber (1985) and Feber and Merrigan (1987).

\section{COMPATIBUITY AND LIEE STUDIES}

Understanding of materials compatibility and corrosion problems is essential to the proper design and long term operation of liquid metal heat pipes. Deverall (1970) presented life test data on a 12-inch-long, 0.75-inch-OD Hg-Stainless Steel system operating at $603 \mathrm{~K}$ for 10,000 hours. In these tests the maximum heat flux was $1.06 \mathrm{~kW}$ 
over a 2.25-inch evaporator region. Magnesium was used as an oxygen getter to clean the surface, promoting wetting. Titanium was used as an inhibitor to reduce stainless steel corrosion. Kemme et al. (1978) report test results from a number of liquid metal heat pipes including a $7.3 \mathrm{~m}$ long, $45 \mathrm{~mm}$ i.d., $\mathrm{Hg}$-Stainless Steel heat pipe operating up to $27 \mathrm{~kW}$ at $650 \mathrm{~K}$ in a vertical gravity-assist mode.

Ceramic heat pipes were developed for use in high temperature heat recovery in process heat furnace recuperators Keddy and Ranken (1979), Merrigan and Keddy (1982), and Merrigan et al. (1981). Operation of sodium heat pipes in air at temperatures in excess of $1200 \mathrm{~K}$ was accomplished using $\mathrm{SiC}$ as a shell material and a chemical vapor deposit tungsten inner liner for protection of the ceramic from the working fluid. Throughput was about $2-\mathrm{kW}$ with a $19-\mathrm{mm}-\mathrm{ID}$ pipe with repeated start cycles having temperanire rise rates in excess of $1.2 \mathrm{~K} / \mathrm{s}$.

Merrigan (1985) provides the results of a 1700 hour test of a Li-Mo heat pipe operating at $1500 \mathrm{~K}$ with an axial heat flux of $11 \mathrm{~kW} / \mathrm{cm}^{2}$ and an evaporator radial heat flux of 70 W/ $\mathrm{cm}^{2}$. Lundberg and Merrigan (1984), Lundberg and Feber (1984), and Lundberg (1987) present the results of tests with cladded $\mathrm{Na}-\mathrm{Mo}-\mathrm{UO}_{2}$ combinations operating at around $1400 \mathrm{~K}$ for up to 28,432 hours and Li-Mo operating at $1700 \mathrm{~K}$ for 25,216 hours before failure. Corrosion mechanisms were attributed to the transport of impurities such as $\mathrm{Ni}, \mathrm{O}, \mathrm{C}, \mathrm{Si}$, and $\mathrm{N}$ into the evaporator region. These transport mechanisms were then modeled theoretically. Oxygen-induced corrosion in potassium heat pipe is described in Lundberg (1987). A thermochemical corrosion model for both Mo-alkali metal systems and $\mathrm{Nb}$-alkali metal systems is described in Merrigan and Feber (1985) and Feber and Merrigan (1987). On going compatibility tests of $\mathrm{K}-\mathrm{Nb}-1 \% \mathrm{Zr}$ heat pipes operating at around $850 \mathrm{~K}$ are summarized in Sena and Merrigan (1990).

The results of a 45,036 hour test with a $\mathrm{Na}-\mathrm{Mo}-\mathrm{TZM}$ heat pipe operating at $1400 \mathrm{~K}$ is presented in Lundberg (1987). Data on $\mathrm{K}-\mathrm{Ni}, \mathrm{K}-\mathrm{Ti}, \mathrm{Li}-\mathrm{Ta}, \mathrm{Li}-\mathrm{Nb}-1 \% \mathrm{Zr}$, and $\mathrm{Li}-\mathrm{Mo}$ systems are also given. This paper also reviews liquid metal heat pipe lifetime and compatibility tests conducted at Los Alamos and elsewhere.

\section{SPACE POWER RELATED APPLICATIONS}

\section{Orbital Heat Pipe Experiment}

The first orbital heat pipe was flown aboard an Atlas-Agena launch vehicle in April 1967. The heat pipe was a simple 12 -inch-long water-stainless steel system described in Deverall and Kemme (1965), Deverall et al. (1967a), Deverall and Salmi (1967), Deverall et al. (1967b), and Grover et al. (1968). The experiment ran successfully for 51 hours before the satellite's battery voltage became too low for signal transmission. The experiment demonstrated that the absence of gravitational forces does not affect heat pipe performance.

\section{SPAR and SP-100 Reactor Programs}

The LANL SPAR reactor program was the predecessor of the current DOE SP-100 program. The SPAR system was based on thermoelectric conversion with the heat pipes coupled directly into the reactor core. This design posed a number of technological challenges, not the least of which was the need for two or more bends of nearly $90^{\circ}$ in the heat pipe to go around the reactor's radiation shield. The SPAR program produced a number of significant advances in liquid metal heat pipe technology in the areas of fabrication, axial and radial power density, and startup methods. A general overview of space reactor related heat pipe technology issues is provided in Merrigan (1985).

The fabrication and bending of Li-Mo heat pipes with annular screen wicks is described in Lundberg and Martinez (1980). These pipes were bent and successfully operated at 1 
$\mathrm{kW} / \mathrm{cm}^{2}$ axial heat flux between 1400 and $1700 \mathrm{~K}$. The construction, testing, and performance correlation of a number of artery $\mathrm{Na}$-Mo heat pipe designs operating in the $1450 \mathrm{~K}$ range is reported in Merrigan et al. (1982). Similar tests were performed with a LiMo TZM compacted artery heat pipe design at $1500 \mathrm{~K}$ in Merrigan et al. (1983a) and Merrigan et al. (1983b). These tests demonstrated axial power levels up to $19 \mathrm{~kW} / \mathrm{cm}^{2}$ and radial heat fluxes in the evaporator up to $300 \mathrm{~W} / \mathrm{cm}^{2}$. A study examining the suitability of Mo-13\%Re for reactor heat pipe operation is given in Merrigan and Lundberg (1983).

A demonstration of the operation of a flexible Na-stainless steel heat pipe operating at $1100 \mathrm{~K}$ is described in Merrigan et al. (1984). This heat pipe was flexed repeatedly through angles of $18 \mathrm{C}$ degrees both at room temperature and at its operating temperature. The start-up, shut-down, restart, and peak power of an annular Li-Mo heat pipe operating at $1500 \mathrm{~K}$ was characterized in Merrigan et al. (1985) and Merrigan et al. (1986). Maximum power throughput in the tests was $36.8 \mathrm{~kW}$, corresponding to a power density of $23 \mathrm{~kW} / \mathrm{cm}^{2}$ for a $1.4 \mathrm{~cm}$ diameter vapor space. The evaporator heat flux was approximately $150 \mathrm{~W} / \mathrm{cm}^{2}$ over an evaporator length of $40 \mathrm{~cm}$ at peak power.

The current DOE SP-100 reactor design uses K-Nb-1\% Zr heat pipes at over $750 \mathrm{~K}$ as a part of its main radiator. Numerous alternative radiator designs have been proposed to reduce the weight of the existing baseline design. One of these alternative designs is a K-Ti radiator consisting of 360 , D-shaped, 5.2-m long, $3 \mathrm{~kW}$ heat pipes operating at $775 \mathrm{~K}$. The construction and testing of prototypes of these K-Ti heat pipes is described in Girrens et al. (1980), and Girrens (1982).

Experimental lifetime performance studies are currently in progress (Sena and Merrigan, 1990) with six of eight originally operating K-Nb1\% $\mathrm{Zr}$ heat pipes between 850 and $950 \mathrm{~K}$. These pipes have been operating in excess of 10,000 hours at axial heat fluxes of over $180 \mathrm{~W} / \mathrm{cm}^{2}$. The operation of a K-Nb-1\%Zr heat pipe operating with radial heat fluxes in the evaporator region of up to $147 \mathrm{~W} / \mathrm{cm}^{2}$ at $925 \mathrm{~K}$ is described in Woloshun et al. (1990a).

\section{Thermal Energy Storage}

The organic Rankine cycle solar dynamic power system was a candidate to provide the Space Station with constant power during both insolation and eclipse. This system incorporates thermal energy storage canisters within the vapor space along with an organic fluid heater tube used as the condenser region of the heat pipe. Potassium heat pipes in Keddy et al. (1987), Keddy et al. (1988a), and Keddy et al. (1988b) were developed to absorb and transfer solar energy within the receiver cavity operating between 725 and 775 $\mathrm{K}$. A heat pipe assembly incorporating $\mathrm{LiOH}$ energy storage was fabricated and tested at a nominal design input of $4.8 \mathrm{~kW}$ and a maximum input of $5.7 \mathrm{~kW}$.

\section{Hypersonic Vehicle Leading Cooling}

The cooling requirements for the wing and engine ducting leading edges of the proposed National Aerospace Plane (NASP) exceed the limits of demonstrated heat pipe technology. A Li-Mo heat pipe operating with tip temperatures in excess of $1900 \mathrm{~K}$, was operated at tilt angles between 10 and 90 degrees from the horizontal with radial heat fluxes between 800 and $550 \mathrm{~W} / \mathrm{cm}^{2}$, in an investigation of NASP heat pipe applications by Merrigan and Sena (1989). Both radio frequency (rf) plasma jet and direct rf induction heating methods were used. The higher heating rates were achieved with using direct $\mathrm{rf}$ induction with a concentrator. 


\section{Gás-Controlles_Liquid_Metal_Heat_Pipes}

Rankine (1990) describes tests performed on a total of 29 Neon-filled stainless steel heat pipes having either $\mathrm{Na}$ or $\mathrm{K}$ as a working fluid. The heat pipes varied from 10.3 to 28.0 $\mathrm{mm}$ in diameter and 194 to $540 \mathrm{~mm}$ in length. Heat transport capacity varied from 500 to over $5000 \mathrm{~W}$. The operating temperature ranged from $850 \mathrm{~K}$ to $1100 \mathrm{~K}$. These pipes were used as temperature control units for materials irradiation capsules tested in the EBR-II reactor. Unpublished work conducted for the Rockwell Dynamic Isotope Power Subsystem (DIPS) program involved construction and testing of neon-gas-controlled, LiStainless steel heat pipe operating between 1030 and $1230 \mathrm{~K}$ having a maximum axial heat flux of $230 \mathrm{~W} / \mathrm{cm}^{2}$.

\section{Heat Pipe Vapor Cells}

Laser beams with various specific wavelengths can be generated using metal vapor atmospheres in heat pipes. Gas loaded heat pipes with transparent window have been used to produce these atmospheres. Experiments with a stainless steel vapor cell containing a $\mathrm{Hg}-\mathrm{Xe}$ mixture with a typical centerline temperature of $586 \mathrm{~K}$ are described in Deverall and Phillips (1976) and Deverall (1977). The principle objectives of these tests were to determine the effect of heat pipe diameter, buffer-gas density, and convection on the stability of the gas-vapor interface. A neon buffered sodium heat pipe cell Kemme and York (1978) was constructed and successfully operated at $970 \mathrm{~K}$. Unfortunately, this effort failed to produce the desired sodium lasing action and the program was terminated. More recent studies have used $\mathrm{Pb}$-Ar mixtures in alumina and tungsten-tantalum heat pipes Merrigan et al. (1990) and Reid et al. (1990) with quartz windows at around $1573 \mathrm{~K}$ to produce a Raman shift between the UV and the blue. The objective of this last program was to produce an airborne or space-based submarine communication system.

\section{SUMMARY}

High temperature space-power has been the principle emphasis in heat pipe work at Los Alamos since its invention there 28 years ago. Recent heat pipe work at Los Alamos has involved performance testing of typical space reactor heat pipe designs to power levels in excess of $23 \mathrm{~kW} / \mathrm{cm}^{2}$ axially and $800 \mathrm{~W} / \mathrm{cm}^{2}$ radially. Flexible heat pipes intended for use in deployable space radiators have been tested with continuous operation during $180^{\circ}$ bends. Mass transport/corrosion chernistry models have contributed significantly to the understanding of liquid metal heat pipe failure modes and to the prediction of operating life. Controlled life-tests have demonstrated successful heat pipe operation at temperatures above $1700 \mathrm{~K}$ for over 45,000 hours.

\section{Acknowledgments}

This work was supported by the U.S. Department of Energy. 


\section{Beferences}

Costello, F., R.S. Reid, M.A. Merrigan, and A. Montague (1987) "Detailed Transient Model of a Liquid Metal Heat Pipe," 4th Symposium on Space Nuclear Power Systems, Albuquerque, NM, January ¿987.

Cotter, T. P. (1965) "Theory of Heat Pipes," Los Alamos Scientific Laboratory report LA-3246.MS, February 1965.

Cotter, T. P, J. Deverali, G. F. Erickson, G. M. Grover, E. S. Keddy, J. E. Kemme, anu E. W. Salmi (1965) "Status Report on Theory and Experiments on Heat Pipes at Los Alamos," Proceedings of the International Conference on Thermionic Power Generation, London, September 1965.

Cotter, T. P. (1967) "Heat Pipe Start-up Dynamics," 1967 IEEE Thermionic Conversion Specialist Conference, Palo Alto, California, October 30November 1, 1967.

Deverall, J. E. and J. E. Kemme (1964) "High Thermal Conductance Devices Utilizing the Boiling of Lithium and Silver,"Los Alamos Scientific Laboratory report LA-3211, October 1964.

Deverall, J. E. and J. E. Kemme (1965) "Satellite Heat Pipe," Los Alamos Scientific Laboratory report LA-3278-MS, January 1965.

Deverall, J. E. and E. W. Salmi (1967) "Heat Pipe Performance in a Space Environment," (1967) 1967 IEEE Thermionic Conversion Specialist Conference, Palo Alto, California, October 30-November 1, 1967.

Deverall, J. E., E. W.Salmi, and R. J. Knapp (1967a) "Orbital Heat Pipe Experiment," Los Alamos Scientific Laboratory report LA-3714, June 1967.

Deverall, J. E., E. W. Salmi, and R. J. Knapp (1967b) "Heat-Pipe Performance in a Zero Gravity Field," J. of Spacecraft and Rockets.

Deverall, J. E., J. E. Kemme, and L. W. Florschuetz (1970) "Sonic Limitaions and Start-up Problems of Heat Pipes," Los Alamos Scientific Laboratory report LA-4518, September 1970.

Deverall, J. E. and J. R. Phillips (1976) "Metal Vapor Laser Cell," LA-UR-75 1311, II International Heat Pipe Conference, Bologna, Italy, March 31-April 2, 1976.

Deverall, J. E. (1977) "Gas-Interface Studies in Large Horizontal Heat Pipes," Los Alamos Scientific Laboratory report, LA-6646-MS, January 1977.

Feber, R. C. and M. A. Merrigan (1987) "Thermochemical Modeling of Mass Transport in High-Temperature Heat Pipes,"VI International Heat Pipe Conference, Grenoble, France, May 25-28, 1987.

Girrens, S. P., Meier, K.L. and J. M. Dickinson (1980) "Titanium Heat Pipes for Space Power Systems, "LA-UR-80-1033, 15th Intersociety Energy Conversion Engineering Conference, Seattle, WA, August 18-22, 1980. 
Girrens, S. P. (1982) "Design and Development of a Titanium Heat-Pipe Space

Radiator," Los Alamos National Laboratory Report, LA-9251-MS, March 1982.

Grover, G.M., T. P. Cotter, and G. F. Erickson (1964) "Structures of Very High Thermal Conductance," Journal of Applied Physics, 35, 6, pp. 19901991.

Grover, G. M., J. Bohdansky, and C. A. Busse (1965) "The Use of a New Heat Removal System in Space Thermionic Power Supplies," European Atomic Energy Community - EURATOM report EUR 2229.e.

Grover, G. M., J. E. Kemme, and E. S.'Keddy (1968), "Adyances in Heat Pipe Technology," Second International Conference on Thermionic Electrical Power Generation, Stresa, Italy, May 27-31, 1968; Los Alamos Scientific Laboratory report LA-9619, May 1968.

Keddy, E.S. and W. A. Ranken (1979) "Ceramic Heat Pipes for High Temperature Heat Removal," LA-UR-79-332, 18th National Heat Transfer Conference, AIChE-ASME, San Diegn, CA, August 5-8, 1979.

Keddy, E. S., J. T. Sena, and M. A. Merrigan (1987) "Integrated Heat Pipe Thermal Storage System Performance Evaluation," 22nd Intersociety Energy Conversion Engineering Conference, Philadelphia, PA, August 10-14, 1987.

Keddy, E. S., J. T. Sena, M. A. Merrigan, G. Heidenreich, and S. Johnson (1988a) "Develcpment of an Integrated Heat Pipe Thermal Storage System for a Solar Receiver," AIAA Thermophysics, Plasmadynamics, and Lasers Conference, San Antonio, TX, June 27-29, 1988.

Keddy, Edward S., Sena, J. Tom, Merrigan, Michael A., Heidenreich, G. and S. Johnson (1988b) "Transient Performance Evaluation of an Integrated Heat Fipe Thermal Storage System," 23rd Intersociety Energy Conversion Engineering Conference, Denver, CO, July 31-August 5, 1988.

Kemme, J. E. (1966) "Heat Pipe Capability Experiments," Proc. of Joint $A E C /$ Sandia Laboratories report SC-M-66-623,1, October 1966. Expanded version of this paper, Los Alamos Scientific Laboratory report LA-3585-MS (August 1966), also as LA-DC-7938. Revised version of LA-3583-MS, Proc. IEEE Thermionic Conversion Specialist Conference, Houston, Texas, (November 1966).

Kemme, J. E. (1968) "Ultimate Heat Pipe Performance," 1968 IEEE Thermionic Conversion Specialist Conference, Framingham, Massachusetts, October 21-23, 1968.

Kemme, J. E. (1969) "Heat Pipe Design Considerations," Eleventh Heat Transfer Conference, Minneapolis, Minnesota, August 3-6, 1969; Los Alamos Scientific Laboratory report LA-4221-MS, August 1969, and LA-DC-10697.

Kemme, J. E., E. S. Keddy, and J. R. Phillips (1978) "Performance Investigations of Liquid-Metal Heat Pipes for Space and Terrestrial Applications," III International Heat Pipe Conference, Palo Alto, CA, May 22-24, 1978. 
Kemme, J. E. and G. W. York (1978) "Sodium Vapor Heat Pipe Laser Cell," LA-UR-78-532, III International Heat Pipe Conference, Palo Alto, CA, May 22$24,1978$.

Lundberg, L.B. and H. E. Martinez (1980) "Fabrication of High-Temperature (1400$1700 \mathrm{~K})$ Molybdenum Heat Pipes," LA-UR-79-3513, 15th Intersociety Energy Conversion Conference, Seattle, WA, August 18-22, 1980.

Lundberg, L. B. and M. A. Merrigan (1984) "Sodium and Lithium Corrosion in Molybdenum Heat Pipes," in Physical Metallurgy and Technology of Molybdenum and Its Alloys, AMAX Materials Research Center, Ann Arbor, MI, October 29-30, 1984.

Lundberg, L. B. and Roy C. Feber (1984) "Corrosion in Alkali Metal/Molybdenum Heat Pipes," AIAA 19th Thermophysics Conference, Snowmass, CO, June 25-28, 1984.

Lundberg, L. B. (1987) "Alkali Metal Heat Pipe Corrosion Phenomena," VI International Heat Pipe Conference, Grenoble, France, May 25-28, 1987.

Merrigan, M. A., W. E. Dunwoody, and L. Lundberg (1981) "Heat Pipe Development for High Temperature Recuperator Application," IV International Heat Pipe Conference, London, England, September 7-10, 1981.

Merrigan, M. A. and E. S. Keddy (1982) "High-Temperature Heat Pipes for Waste-Heat Recovery," AIAA Journal of Energy, Vol. 6, Number 5, September-October 1982, pp. 298-303.

Merrigan, M. A., C. Prenger, H. E. Martinez, and J. Runyan (1982) "Artery Heat Pipes for Space Power Systems," LA-UR-82-1270, 17th Iniersociety Energy Conversion Engineering Conference, Los Angeles, CA, August 8-13, 1982.

Merrigan, M. A., J. E. Runyan, H. E. Martinez, and E. S. Keddy (1983a)

"Development and Test of a Space Reactor Core Heat Pipc," AIAA 18th

Thermophysics Conference, Montreal, Canada, June 1-3, 1983a.

Merrigan, M. A., E. H. Martinez, E. S. Keddy, J. Runyan, and J. E. Kemme (1983b) "Performance Demonstration of a High Power Space Heat Pipe Design," 18th Intersociety Energy Conversion Engineering Conference, Orlando, FL, August 21-26, 1983.

Merrigan, M. A. and L. B. Lundberg (1983) "An Initial Evaluation of MolybdenumRhenium Alloy for Reactor Heat Pipes," 18th Intersociety Energy Conversion Engineering Conference, Orlando, FL, August 21-26, 1983.

Merrigan, M. A., E. S. Keddy, J. R. Runyan, and H. E. Martinez (1984) "Development and Extended Operation of a High Power Radiation Loaded Heat Pipe," AIAA 19thThermophysics Conference, Snowmass, CO, June 25-28, 1984.

Merrigan, M.A., E. S. Keddy, J. T. Sena, and M. G. Elder (1984) "Heat Pipe Technology Development for High Temperature Space Radiator Applications," 19th Intersociety Energy Conversion Engineering Conference, San Francisco, CA, August 19-24, 1984. 
Merrigan, M. A. (1985) "Heat Pipe Technology Issues," Space Nuclear Power Systems, 1984, Edited by M.S. El-Genk and M.D. Hoover, Orbit Book Company, Malabar, FL, 1985.

Merrigan, M. A. and R. C. Feber (1985) "Thermochemical Correlation of Material Transport in an Alkali Metal Heat Pipe," Society of Automotive Engineers Conference, Miami Beach, FL, August 18-23, 1985.

Merrigan, M. A., E. S. Keddy, and J. T. Sena (1985) "Transient Heat Pipe Investigations for Space Power Systems," SP-100 Program Integration Meeting, Denver, CO, September 19, 1985.

Merrigan, M. A., E. S. Keddy, and J. T. Sena (1986) "Transient Performance Investigations of a Space Power System Heat ripe," AIAA/ASME 4th Joint Thermophysics and Heat Transfer Conference, Boston, MA, June 2-4, 1986.

Merrigan, M. A., Keddy, E.S. and Sena, J.T. (1987) "Performance Correlations for High Temperature Potassium Heat Pipes," VI International Heat Pipe Conference, Grenoble, France, May 25-28, 1987.

Merrigan, M. A. and J. T. Sena (1989) "Evaluation of Heating Methods for High Heating Rates and Design and Demonstration of Heat Pipe Cooling for NASP," 7th National Aero-Space Flane Technology Symposium, October 23-27, 1989.

Merrigan, M. A., K. A. Woloshun, and R. S. Reid (1990) "An investigation of Lead Heat Pipes," VII International Heat Pipe Conference, Minsk, USSR, May 2125, 1990.

Ranken, W. A., and J. E. Kemme (1965) "Survey of Los Alamos and EURATOM Heat Pipe Investigations," Proc. IEEE Thermionic Conversion Specialist Conf., San Diego, California, October 1965; Los Alamos Scientific Laboratory report LA-DC-7555.

Ranken, W. A. (1987) "Irradiation of High Temperature Heat Pipes,"VI International Heat Pipe Conference, Grenoble, France, May 25-28, 1987.

Reid, R. S., K. A. Woloshun, and M. A. Merrigan, (1990) "An Investigation of Lead Vapor Cells," LA-UR-90-674, February 1990.

Sena, J. T. and M. A. Merrigan (1990) "Niobium-1\% Zirconium/Potassium Life Test Heat Pipe Design and Testing," AIAA 28th Aerospace and Sciences Meeting, Reno, NV, January 8-i 1, 1990.

Woloshun, K. A., M. A. Merrigan, and E. D. Best (1988) "HTPIPE: A SteadyState Heat Pipe Analysis Program," Los Alamos National Laboratory Manual, LA-11324-M, November 1988.

Woloshun, K. A., J. T. Sena, E. S. Keddy, and M. A. Merrigan (1990a) "Radial Heat Flux Limits in Potassium Heat Pipes: An Experimental and Analytical Investigation," 7th Symposium on Space Nuclear Power Systems, Albuquerque, NM, January 7-11, 1990. 
Woloshun, K. A., J. T. Sena, E. S. Keddy, and M. A. Merrigan, (1990b) "Boíling Limits in Heat Pipes with Annular Gap Wick Structures," AlAA/ASME 8th Joint

Thermophysics and Heat Transfer Conference, June 18-20, 1990. 

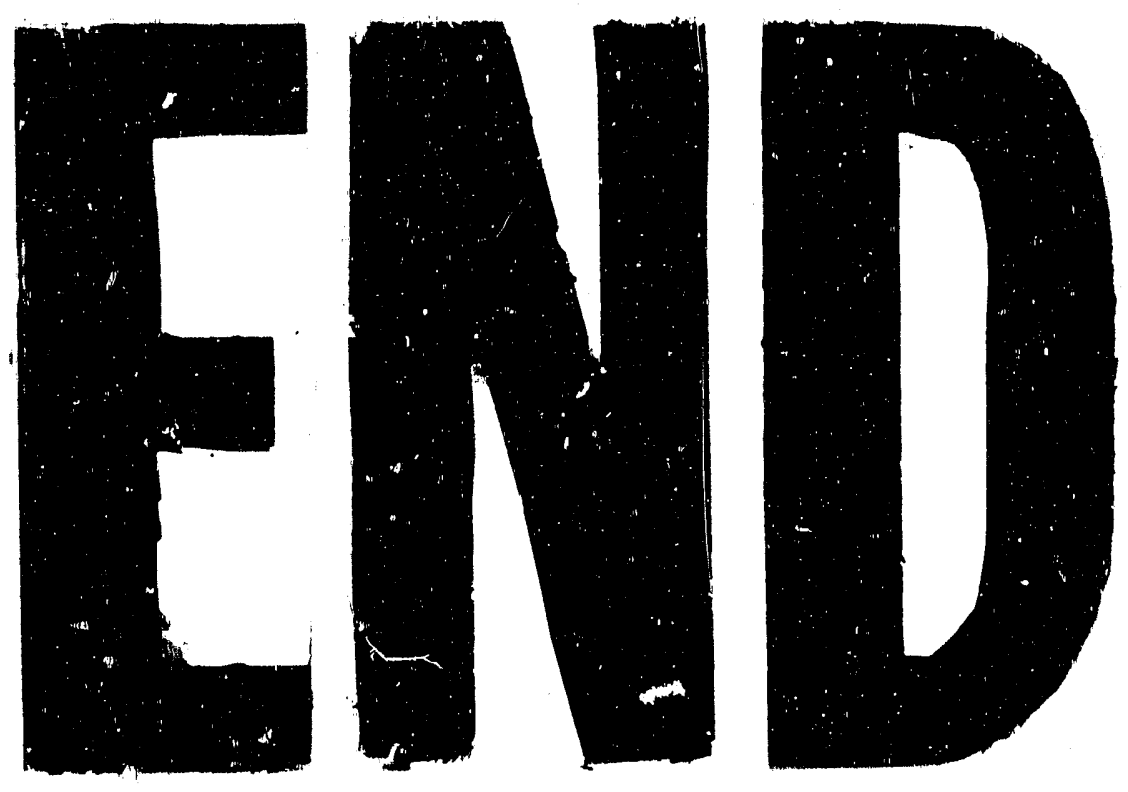

4
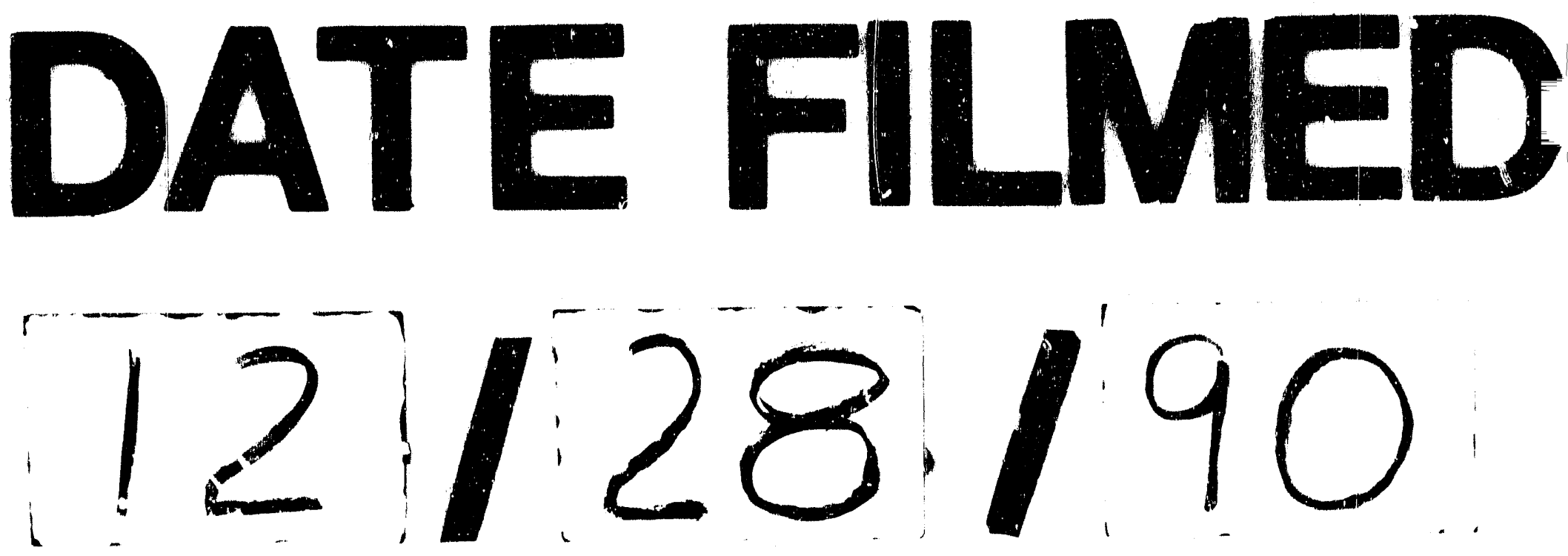
